\title{
Disciplinary Networks in Secondary Schools: Policy dimensions and children’s rights in Tanzania
}

\author{
Regina Slaa Yaghambe \\ Graduate School, University of Arusha, Tanzania \\ E-mail: reginayaghambe@yahoo.com \\ Icarbord Tshabangu, (Corresponding author) \\ Educational Foundations \& Management, University of Namibia \\ Private Bag 13301, Windhoek, Namibia \\ E-mail: itshabangu@unam.na
}

Received: August 23, 2013 Accepted: September 23, 2013 Published: November 1, 2013

doi:10.5296/jse.v3i4.4167

URL: http://dx.doi.org/10.5296/jse.v3i4.4167

\begin{abstract}
The Tanzania Education Act number 25 of 1978 gave powers to the Minister of Education to develop policies that enable management of discipline in schools. The legalized use of corporal punishment in managing student's disciplinary problems emerged from the corporal punishments regulations of 1979 under section 60 of the Education Act. This regulation was moderated in 2000 to enable oversight, but still retained corporal punishment as a method of dealing with major offences in schools.

This research explored the effectiveness of physical punishment including the corporal punishment policy in managing school discipline problems, noting the limitations this method may have and the psychological scars some students tend to have arising from use of corporal punishment. The study was conducted in 10 secondary schools accounting for 50 teachers and 104 students. A descriptive qualitative methodological approach was largely followed, using semi structured questionnaires; interviews and observations to collect data. Quantitative tabulation of some data was only used prior to further qualitative exploration. The findings suggested that the use of physical and corporal punishment method was often degrading to students but less effective. A wide range of abuses of students' rights was noted, a feature which is anathema to the Convention on the Rights of a Child (CRC) and the African Human and People's Rights charter on human rights.
\end{abstract}

Keywords: Disciplinary networks, Policy, Children rights, Secondary schools, Tanzania 


\section{Introduction}

Students' disciplinary problems are one of the major concerns in schools and a major challenge that a teacher may face (Lloyd \& Judyth, 1997; Dunlap, 2007). It is noted that these disciplinary problems can be the main hindrance to effective teaching and learning. Lack of discipline may create an environment that becomes violent and unsafe within a school community resulting in lower achievement rates (Brown, 2003). Disciplinary problems in Tanzanian schools often include truancy, peddling drugs, drug abuse, bullying, taking alcohol, smoking, sexual affairs, abusive language and theft. In the Education Act corporal punishment emerged as a tool to curb these students' misdemeanors.

Corporal punishment is regarded as lawful in Tanzania under the National corporal punishment regulation of 1979 pursuant to article 60 of the national Education Act of 1978 (UNICEF, 2010). The corporal punishment regulations of 2000 retained the tenets of the old Act, but limited the administering of corporal punishment to major offences requiring expulsion or total exclusion from school. The new regulation engendered moderation, putting into consideration students' health status and the girl child. Though school discipline has been stated to be a prerequisite for effective teaching and learning in schools, there are still questions on its effectiveness (Ramsey, 1994 as cited in Orit, 2007), thus this study interrogated the effectiveness of the regulatory policy on schools' discipline such as strokes, noting the limitations of these physical punishment methods in managing students' behaviour.

This study observed that school cultures play a pivotal role in achievement and in developing students into socially responsible citizens and that the disciplinary networks in some schools tended to negate this moral cardinal. In most school environments students learn to regulate their own behavior; respect of other persons in society; learn to manage their time wisely; imbibe various positive philosophies; develop life skills and leadership traits (Stolp, 1994; Prosser, 1999; Lumby, 2003). This study therefore moved to determine the nature of indiscipline in Tanzania 'schools; the perceptions of students and teachers on disciplinary networks and the effectiveness of the disciplinary regulatory policy in creating a safe and conducive learning environment that produce responsible citizens.

\section{Aims of School discipline}

Mbiti cited in Simatwa (2002) noted that the major aims of discipline both in the school and in the home should be to nurture young people who will be responsible citizens in future. The aim of school discipline should therefore be seen to help students cope well, be happy, safe and useful to the society they belong (Nakpodia, 2010). It has been noted that a culture of physical punishments may increase aggressiveness if it is demonstrated that aggression is a way to cope with the problems. This explains as to why most aggressive delinquents and abusive parents tend to be products of abusive households (Straus et al, 1980; Myers, 2003) and that frequently spanked kids are at increased risk for aggression, depression and low self-esteem (Myers, 2003).

Since the aims and objectives of the Education and Training policy in Tanzania are stated as meant to inculcate a sense of self confidence, to develop enquiring minds in students, to 
develop respect for human dignity and to make students socially responsible for the nation's welfare (Ministry of Education \& Culture, 1995), aggressive forms of disciplining students are most unlikely to churn out graduates laden with positive values as stated above. It has been noted that, 'education processes ought to take into account the whole child', that the adjustment and learning facets of the child must not be separated, integrating also the teacher's personality which is considered a significant factor of the relationship (Rhodes \& Michael, 1974). Teachers may need to rethink the cultures they bring into schools; particularly the unjust and often sadistic ways of applying punitive measures (Tshabangu, 2008). As models, teachers' behaviors and expectations have a greater influence on students' behavior even later in life (Cole et al, 2005).

\section{School disciplinary trends}

Disciplinary problems are a major challenge that teachers face (Llyod \& Judith 1997). It has been established that students engage in unaccepted behaviors in schools due to a variety of reasons including living in dysfunctional homes, going to school hungry, being tired or upset, being bored, due to use of drugs and drug abuse, family conflicts and parents separation, peer pressure, teachers' authoritarian nature and lack of commitment on the part of students (Lloyd \& Judith 1997; Yahaya et al, 2009; Tshabangu, 2008). Bad behavior is often a sign that the child has difficult in coping with the environment, or feelings of uncertainty or unhappiness about the future culminating also in loneliness and the inability to make friends easily.

The most common misbehaviors among students that teachers face are work avoidance, talking out of turn, lack of punctuality, unnecessary noise, physical abuse of other students, rowdiness which includes bullying, vandalism, alcohol consumption, substance abuse, truancy, lack of willingness to study at home and theft ((Lloyd \& Judith, 1997; Kiggundu, 2009).

\section{The contested nature of school discipline}

The concept of 'loco parentis' allows schools to have considerable authority and responsibility in caring for students and disciplining them. In a broader context, teachers have a right to discipline students who contravene school regulations (Nakpodia, 2010). But, despite the fact that corporal punishment may be a legal statutory instrument, it is argued that punishments should only be a last resort when all possibilities for peaceful settlement has failed (Fenwick \& Smith, 1994), and should not be demeaning or used as a behavior management tool (Tshabangu, 2008). Corporal punishment in some schools is often done in excess and that some rules are set without students' participation hence leading to students resistance and breaking of these at times (Tshabangu, 2008; Kiggundu, 2009). Several research findings have continued to challenge the use of punishments as a means to manage students' discipline (Losen, 2011, Dunlap, 2007) as some teachers admit to striking first and seeking for explanation later, claiming lack of time and energy to talk to students”.

The continued recurrence and surge of disciplinary problems in some of Tanzanian schools despite use of physical punishment may serve as an indicator that the physical punishment approaches may not be effective. It is noted that teachers who go on to personally brutalize 
students for a desire to bring about a utopia of harmony in schools often do it to satisfy own ends and mostly do not adhere to statutory regulations (Tshabangu, 2008). According to the African Charter on Human and people's Rights article 5 it can be argued that Corporal punishment indexes a violation of children's rights within some schools. The unnecessarily harsh disciplinary policies are often applied unfairly and disproportionately to some students, which in turn, negatively affects their academic achievement and preparation as democratic citizens (Tshabangu, 2008, Losen, 2011).

\section{Creating Safe Zones amid Ineffectiveness and Abusive Environments}

Research has established that physical punishment is an ineffective form of managing discipline and that it rarely motivates students to act differently (UNICEF 2010; Curwin et al, 2008). William (2009) points out that, conventional strategies to manage discipline are often conduct codes, security methods and suspensions but he maintains that these strategies have proven to be ineffective and contribute to increased disorder in schools leading to more behavioral and academic problems among school children. The harsh and punitive disciplinary policies, plus punishments such as expulsion and suspensions, often do not improve discipline and behavior of students but create an environment that is negative for studies and may increase school dropout rates, underperformances and delinquencies (Skiba \& Peterson, 2000; Maag, 2001).

The abusive punishments often increase hostility within the school environment, fostering a sense of resentment in the school rather than engender positive values. It is noted that some children live in communities where violent and aggressive behaviors are an everyday occurrence in their lives, thus if they are to grow up to be responsible adults, there ought to be an arena in their lives that is safe, and where they can learn and practice appropriate social skills to solve problems without aggression or violence, and schools ought to provide such environments (Mayer, 1995). Most children's behavior and their dreams are often motivated by ideals and these need to be strengthened by a conviction of their personal dignity and worth (Fredericksen \& Mulligan, 1972). Schools therefore need to provide students with proper environments that develop and support the fulfillment of their dreams, where peace and tranquility prevails. It is noted that in some schools disciplinary policies are typically designed to react rather than be proactive so as to prevent dangerous and disruptive behavior. The schools that are proactive tend to provide support for students with challenging behavior; conduct staff development on managing student behavior and encourage family and community involvement which greatly enables the schools to provide an environment that is safe and conducive for learning (Sugai, 1998, Sugai \& Horner, 1999). Furthermore, proactive schools often enforce rules fairly, unambiguously, with a clear rewards and recognition systems for compliance (Smit, 2010).

The administration of corporal punishment on children develops traumatic disorders in the learning environment which results in aggressive behavior, avoidance behaviors, change in personality, fearful reactions, somatic complaints, withdrawal, memory and memory concentration disorders, dependency and regression, habit disorders and sleep disturbances for some students (Cicognani, 2004), thus, it has been noted that there is a significant 
relationship between punishments and academic achievements and successes later in life (Straus, cited in Cicognani, 2004). Corporal punishment is seen as degrading and humiliating and may make students angry and use verbal attacks to other students and teachers (Human Rights Watch, 2008).

\section{Children's Rights and Abuses}

In 1991 the Tanzania government ratified the Convention on the Rights of the child (CRC) and the Human and People's Rights charter, but such ratification has not trickled down to effect positive changes on children's rights, particularly in view of sadistic beatings by teachers or adults who act ultra vires in applying physical and corporal punishments (Simatwa, 2002).

The Nyalalis' commission established by the Tanzania government in 1991 found damning evidence against the use of corporal punishment in schools as a method of managing student's discipline. The Commission reported that, teachers did not adhere to the regulations hence the Government was required to review the regulation. In Tanzanian almost $60 \%$ of young people both male and female experience physical violence from adult relatives and that more than half experienced physical violence from teachers before turning 18 years of age and that over 7 in 10 females and 6 in 10 males of 13 to 24 years of age, experienced physical violence prior to age 18 and also reported physical violence by teachers (UNICEF 2011). Such a violent pattern of disciplining students may unconsciously cause teachers to perceive themselves as enforcers of discipline rather than modelers of good behavior, thereby lose opportunity for self-introspection. According to Bandura (1963), teachers are social variables that influences and model behavior within schools and the classroom. Teachers can model both good and bad behavior because social theory states that, children often times imitate adult's behavior. An act such as the administration of corporal punishment can be imitated elsewhere by students when faced with a similarly frustrating situation in their life relationships.

Acts of physical punishment are seen as childish and tend to belittle the significance of power of the person being punished (McIntire, 1996). These punishments often encourage children towards habits such as nail biting, hair twirling, and "safer obsessions" like TV and video games. These safer habits occur because children want to avoid their punisher. When children are not encouraged and rewarded these habits will increase (McIntire, 1996). Furthermore, physical punishment does not provide enough information; it only tells the child what he ought not to do, but rarely what the child ought to do (McIntire, 1996).

\section{Alternate methods to physical punishments}

Children's social behavior can be modeled positively when teachers see themselves as role models for pupils and expertly create deliberate interactions in classrooms in such a way as to foster satisfaction than frustrations. Under such an environment, cooperation, efficiency, cohesion, trust and mutual identification is most likely to result since it is believed that teachers are also aware that classroom experiences provide opportunities for children to mature socially and acquire knowledge (Wolf, 1971). A view is advanced that the proper 
process of managing discipline is by constantly emphasizing positive behavior and that the action needs to maintain both students and teachers dignity' (Curwin et al, 2008). When disciplinary measures are used excessively they frustrate students (Ofuyuru \& Lawrence, 2011). Yang (2009) argues that "interventions based on robotic protocol, heavy use of suspensions and expulsions and rule-bound approaches that prescribe same treatment for dissimilar offenses do not improve school climate and do not reduce incidents of violence”. Hughes et al, (1985) further contended that teachers, parents and pupils needed to create positive relationship for the effectiveness and harmonious function of a school without a climate of hostility.

\section{Methodology}

The study followed qualitative methodology which provided in-depth, intricate and detailed understanding of meanings, actions, observable and non-observable phenomena, attitudes, intentions and behaviors (Cohen, Manion \& Morrison 2011, Kothari, 2006). It helped the study to give voices to participants as it probed issues that lie beneath the surface concerning disciplinary networks in Tanzanian schools.

Using non probability sampling the study was conducted in 10 secondary schools involving 50 teachers and 104 students. A descriptive qualitative methodological approach was followed, using semi structured questionnaires; interviews and observations to collect data. The data collection was conducted by one researcher but across a broad section of participants and using different instruments which enabled rigor and triangulation as part of enhancing validity in the study.

The study used simple and unambiguous language (Bell, 1993), according to age and level of education of respondents, observing consent and confidentiality. Quantitative tabulation of some data was only used prior to further qualitative analysis of data using Critical Discourse Analysis which is seen as aiding the less powerful groupings (Fairclough, 2000). This helped to form patterns of meanings which organize various symbolic systems that human beings inhabit (Parker, 1999), and which are necessary in making sense of their social world.

\section{Results of the study}

\subsection{Teachers Responses}

The study was conducted in ten (10) secondary schools in Arusha. Five participants at each school were teachers who had taught in secondary schools for more than one year up to 30 years in the field. This enabled the researcher to get their varying experiences in handling disciplinary challenges involving students. Tabulated below are responses from teachers' perceptions. 
Table 1. Disciplinary problems prevalent in schools

\begin{tabular}{|l|l|l|}
\hline Indiscipline & Frequency & Percentage \\
\hline Truancy & 27 & $54 \%$ \\
\hline Use of drugs & 16 & $32 \%$ \\
\hline Lack of punctuality & 12 & $24 \%$ \\
\hline Involvement in love and sexual affairs & 8 & $16 \%$ \\
\hline Use of abusive language & 7 & $14 \%$ \\
\hline Disobedience & 5 & $10 \%$ \\
\hline Improper school uniforms & 3 & $6 \%$ \\
\hline Use of alcohol & 5 & $10 \%$ \\
\hline Use of cellular phones & 2 & $4 \%$ \\
\hline Lying & 1 & $2 \%$ \\
\hline Cigarette smoking & 5 & $10 \%$ \\
\hline Noise making & 6 & $12 \%$ \\
\hline Theft & 3 & $6 \%$ \\
\hline Not attending church & 1 & $2 \%$ \\
\hline
\end{tabular}

From table above, it is clear that, schools experience a wide range of disciplinary problems on a daily basis. The minor disciplinary problems that were experienced were, not attending church, lying, disobedience, improper school uniforms, use of cellular phones at school, use of alcohol and cigarette smoking. On the other hand, the major offences are seen as truancy, drugs and drug abuse, lack of punctuality and absenteeism and involvement in sexual affairs.

The table below indicates the forms of punishment meted out to students as part of managing the above stated misdemeanors. The punishments mentioned varied from, striking students, suspension, counseling, manual work like watering gardens, cleaning toilets, mopping schools corridors, expulsion, pushups, and psychological harassment (Llyod and Judith, 1997). It was noted that physical and corporal punishments are much more frequent compared to counseling for example. This raises the issue of disproportionate application of punishments (Yang, 2009) where teachers find comfort in prescribing same treatment for dissimilar offenses.

Table 2. Punishment methods mostly used

\begin{tabular}{|l|l|l|}
\hline Punishments & Frequency & Percentage \\
\hline Strokes & 37 & $74 \%$ \\
\hline Manual work & 25 & $50 \%$ \\
\hline Counseling & 10 & $20 \%$ \\
\hline Suspensions & 9 & $18 \%$ \\
\hline Pushups & 3 & $6 \%$ \\
\hline Kneeling down & 5 & $10 \%$ \\
\hline Psychological harassment & 1 & $2 \%$ \\
\hline Expulsion & 5 & $10 \%$ \\
\hline
\end{tabular}




\subsection{Students'Responses}

The study consisted of 104 students' participants. Among the participants, girls were 50 and boys were 54 . The age of students ranged from 12 years old to 20 years old. The reason about the ages selected is that, students of this age are normally attending secondary education from Ordinary level to Advanced level. Concentration on the participants ages were those of 17 years old, who were 38 , equivalent to $36.5 \%$, followed by those of 16 and 18 years old, who accounted for $18 \%$ each. The findings below are a summation of students' perceptions on disciplinary issues.

Table 3. Frequent offenses committed by students

\begin{tabular}{|l|l|l|}
\hline Discipline problems & Frequency & Percentage \\
\hline Truancy & 52 & $50 \%$ \\
\hline Lack of punctuality & 28 & $26.92 \%$ \\
\hline Use of abusive language & 23 & $22.1 \%$ \\
\hline Lack of commitment to studies & 20 & $19.2 \%$ \\
\hline Theft & 18 & $17.3 \%$ \\
\hline Use of drugs and drug abuse & 18 & $17.3 \%$ \\
\hline Involvement in love affairs & 11 & $10.57 \%$ \\
\hline Fighting & 11 & $10.57 \%$ \\
\hline Lying & 3 & $2.88 \%$ \\
\hline Improper school uniforms & 19 & $18.2 \%$ \\
\hline Disobedience & 31 & $29.8 \%$ \\
\hline Destruction of public property & 6 & $5.6 \%$ \\
\hline Use of alcohol & 7 & $6.7 \%$ \\
\hline Use of cellular phones & 9 & $8.6 \%$ \\
\hline Noise making in the class & 4 & $3.8 \%$ \\
\hline
\end{tabular}

Truancy was stated as a major disciplinary problem by $50 \%$ of the students. Lack of punctuality, including coming to school late rated 26.9\%, use of abusive language and lack of commitment to studies by $22.1 \%$, theft and drugs abuse by $17.3 \%$. Other minor infractions mentioned were, the use of alcohol, use of cellular phones, disobedience, lying, fighting, involvement in love and sexual affairs, improper school uniforms and vandalism. The punishments mentioned in table 4 as frequent by students were strokes by $83.6 \%$, doing manual work by $66.3 \%$, suspension by $50.9 \%$ and expulsion by $23 \%$. This reinforces a view that teachers tend to use physical and corporal punishment even for minor offences. There was no mention of students' counseling in any of the committed offenses even though about $20 \%$ of teachers claimed to exercise counseling. 
Table 4. Punishments administered by teachers

\begin{tabular}{|l|l|l|}
\hline Punishments & Frequency & Percentage \\
\hline Stokes & 86 & 83.6 \\
\hline Doing manual work & 69 & 66.3 \\
\hline Suspensions & 53 & $50.9 \%$ \\
\hline Expulsion & 24 & $23 \%$ \\
\hline
\end{tabular}

\section{Further Discussions of Findings}

\subsection{Effectiveness of Physical and Corporal Punishments}

The administering of discipline by teachers was often seen by students as brutal, unfair and disproportionate. One student stated that "some teachers give double punishments because in the process of doing punishments students also miss classes". Teachers lacked knowledge of the policy guidelines as one teacher stated that 'I don't know how it looks like and where to find it.' Most teachers in interview sessions expressed lack of knowledge on existing regulations and its contents. This came as no surprise in view of wide spread application of strokes and corporal punishment even on minor offenses. One teacher commented on the use of strokes as follows, "It is a tradition. It has always been like this. I was harshly punished as a student and now that I am a teacher I have to punish students under me”. Clearly, such perceptions by teachers tend to militate against following policy guidelines to the letter. It is therefore such beliefs and practices by teachers including their lack of knowledge of limits placed upon them by policy, which renders the policy on regulation of corporal punishment ineffective. Most teachers at 58\% acknowledged that there was no adherence to the corporal punishment regulations. This implies that most teachers are aware that, the corporal punishment regulations are not followed as promulgated in statutory guidelines.

It was found that, corporal punishment was being administered by all teachers at the researched schools without the prior approval of the head of school contrary to regulation guide line number 3 and 4 in the Corporal Punishment Regulation of 2000. The use of corporal punishment even on minor offenses was also noted as a violation and of concern. When teachers were asked to state if the physical punishments administered on students were effective in managing students' behavior problems, $70 \%$ of the teachers said it was not effective even though more than half of them thought these should be maintained.

\subsection{Violation of Children's rights}

Convention on the Rights of the Child (CRC) Article 28 and 37 requires governments "to give physical and mental protection to children. The Convention states that, it is a child's right to access education and to enjoy special attention,...to enable the child to develop morally, physically, mentally under conditions of freedom and dignity” (UNICEF, 1999), where discipline in schools shuns violent tendencies but promotes respect for children's dignity.

Students' accounts stated cases where they were punished without regard to their dignity by 
being verbally abused through words such as 'you fool', 'stupid', and 'idiot'. These were stated as an everyday encounter in schools, and mostly in front of their fellow students, parents and other teachers. The words did not only cause students to be humiliated, but also made them angry because their dignity had been abused. As a result some students tended to hate school and teachers. In the students' accounts, several students stated that, sometimes they are bitten up to twelve strokes, sometimes they cannot count. Several students only referred to these violations as "terrible beatings". One student commented that "some teachers have made themselves 'semi-gods'; they come to class late and spend most of the time for lesson punishing students. They have forgotten that, we too have our rights though we need education from them'.

Another student also wrote, 'we come to school not because of their beatings, but because we know what we are after. It is ugly to be punished, but there is no glory in punishing'. One student observed that 'beatings does not make student wise and clever, but it only hurts a student and it kills body cells'. Some students even asked the researchers on how to help them solve the terrible punishments they receive daily.

Another student further stated that 'sometimes you are punished by chopping firewood one meter long and wide or to mop all corridors and stairs in school or to sit in the sun the whole day while others are in the class studying'. It was noted that some of the methods used to punish students befitted torture. One teacher recorded that; 'teachers do not care to find out the students' health status nor age prior to administration of corporal punishment'. This meant that students were being brutalized even those with health concerns. In all these abuses, students are expected to obey without question. A student lamented that, 'teachers do not care because we are not their children. They just beat us until some students are not able to write due to swollen fingers and palms'.

Another student further added that, 'sometimes some students are beaten until they become unconscious, or until when the teacher is satisfied'. During an interview, one teacher clearly stated that, 'when I punish a student, I punish him/her until I feel satisfied. I can even strike the student if I do not have a stick right there'. The notion of a teacher being 'satisfied' symbolizes a punishing reminiscent of the $17^{\text {th }}$ century spectacle of the scaffold, that was sadistically seen as demanding reparation not because the offender has brought injury to anyone, but because the right of the superior man (the prince) is violated and because it offends the dignity of his character (Foucault, 1997). In this case the teacher's hierarchical authority, which Freire (1970) claims is sometimes confused with professional authority passes off the teacher as the prince or the sovereign and that the breaking of a school rule is seen as attacking the dignity of his or her person, hence the need to punish until satisfied. Some students argued that strokes given to students only made them to be afraid of teachers and created hatred between a teacher and students, something that negatively affected learning or caused some students to drop from schools.

\subsection{Unfair punishments}

There were several claims by students that teachers are biased towards some students and that punishments are sometimes not equally applied. They stated that some students are severely 
beaten while other students are punished moderately or not punished at all. It was noted that some teachers can be biased towards some students based on academic ability. This means that, teachers have teacher pets and pet hates (Petty, 2004).

\subsection{Abolishment of corporal punishment}

Less than half the number of teachers felt that corporal punishment should be abolished. These represented $48 \%$ while $52 \%$ did not concur. Based on teachers' unwillingness to abolish physical and corporal punishments, this practice may continue unabated in most schools. Still on the abolishment of corporal punishment, $40.4 \%$ of the students were for the abolition of corporal punishment while $59.6 \%$ were against the abolition of the corporal punishment in schools. This means that the majority of students just as teachers do not agree that corporal punishment should be abolished in Tanzanian schools. Some teachers argued that, it is impossible to make students obey and follow instructions without using sticks. Most students also seemed resigned to their rights being violated through 'terrible beatings'. Such perceptions by most teachers and students may be interpreted as fatalistic in nature. Fatalism is sometimes interpreted as docility. This docility, which is always related to the power of destiny or fate, inevitably forces the oppressed to have a distorted view on their situation (Freire, 1970: 43), resulting in fatalistic attitudes such as 'what can l do? I am only a peasant' or 'it is the will of God - as if God were the creator of this organized disorder.' The fatalistic attitude reflected in students' data in earlier accounts was their resignation to being beaten by teachers, a fatalistic attitude often arising from 'self-depreciation' (Freire, 1970: 45). This is where the 'boss' or 'professor' knows all and some students 'become convinced of their unfitness.' Teachers also see it as destiny as one teacher earlier remarked 'It is a tradition. It has always been like this. I was harshly punished as a student and now that I am a teacher I have to punish students under me".

\section{Conclusions}

The study sought to understand the nature of offences committed by students and the frequent punitive measures applied by teachers. It further interrogated the effectiveness of the regulatory policy on schools' discipline, noting the limitations of physical and corporal punishment methods in managing students' behavior. Although corporal punishment is still legal in Tanzania under the Education Act of 2002, and is still a widely used method of punishment, most teachers noted that it was ineffective in managing students' behavior. Students also recorded wide ranging abuses and violations of their rights in the application of physical punitive measures by teachers. Also noted was the unfairness and disproportionate application of punishments.

It was noted that school cultures play a pivotal role in students' achievement and in developing students into socially responsible citizens and that the disciplinary networks in some Tanzanian schools tended to negate this moral cardinal. Because of wide spread abuses and lack of teacher regulation in the application of punitive measures, the policy on corporal punishment was deemed ineffective and a precursor to several violations of children's rights.

Schools may need to apply proactive measures as opposed to reactionary approaches in 
dealing with students' disciplinary challenges. The corporal punishment may need re-examining in ways that observe children's rights and provide teachers with more insight on how to handle disciplinary issues positively.

\section{References}

Babcock, P. (2009). The rational adolescent: Discipline policies, lawsuits, and skill acquisition. Department of Economics: University of Carlifornia.

Bandura, A., \& Walters, R.H. (1963). Social learning and personality development, United States of America: Rinehart and Winston, Inc.

Bell, J. (1993). Doing your research project. Buckingham: Open University Press.

Burke, R. R. (1995). Communicating with students in schools. $3^{\text {rd }}$ edition, Boston: University press of America, Inc.

Cicognani, L. (2004). To punish or discipline? Teachers' attitudes towards the abolition of corporal punishment (Unpublished thesis)

Cohen, L., Manion, L., \& Morrison K. (2011). Research methods in Education, ( $7^{\text {th }}$ edition) U.S.A: Routledge.

Cole, M., Cole, S. R., \& Lightfoot, C. (2005). The development of children. England: Worth Publishers.

Curwin, R. L., Mendler, A., \& Mendler, B. D., (2008). Discipline with dignity, $3^{\text {rd }}$ edition, U.S.A: Association for supervision and curriculum and curriculum development.

Dunlap, G. D. (2007). The effectiveness of the students' responsibility center, Discipline process in addressing disruptive student, Michigan: Michigan State University.

Fairclough, N. (2000). Language and Neo-liberalism. Discourse and Society, 11(2), 1-2. http://dx.doi.org/10.1177/0957926500011002001

Felix, E. E. (2011). Modern approach to classroom discipline, U.S.A: Xlibris Corporation

Fenwick, E., \& Smith, T. (1994). Adolecence. London: Dorling Kindersley Ltd.

Foucault, M. (1977). Discipline and punish: The birth of the prison. New York: Vintage books

Franzoi, S. L. (2003). Social Psychology, $3^{\text {rd }}$ Edition. U.S.A: Mc Graw-Hill

Fredericksen, H., \& Mulligan, R.A. (1972). The child and his welfare. San Francisco U.S.A: W.H Freeman \& Company

Freire, P. (1970). Pedagogy of the Oppressed. London: Penguin.

Hughes, B., Sullivan, H. J., \& Mosley, M. L. (1985). External Evaluation, Task Difficulty, and Continuing Motivation. Journal of Educational Research, 78, 210-15.

Hughes, M., Ribbins, P., \& Thomas, H. (1985). Managing Education, the system and the 
institution. London: IIolt, Rinehart \& Winsl Ltd.

Human Rights Watch. (2008). A Violent Education: Corporal Punishment of Children in US Public Schools. Retrieved May 25, 2013 from: http://www.hrw.org/reports/2008/08/19/violent-education

Kiggundu, H. (2009). An influence of discipline management by head teachers on students academic performance in selected secondary schools of Busiro County in Wakiso district, Kenya (Unpublished thesis)

Kothari, C (2006). Research Methodology, ( ${ }^{\text {nd }}$ edition), New Delhi: New age international publishers.

Lloyd, L., \& Judyth, S. (1997). Meeting the challenges of primary schooling, London: Rutledge

Losen, D (2011). Discipline policies, successful schools, and racial justice. U.S.A- Civil rights project: University of California,

Lumby, J. (2003). Culture Change: The Case of Sixth Form and General Further Education Colleges, Educational management and administration. 31(2), 159-174. http://dx.doi.org/10.1177/0263211X0303102104

Maag, J. W. (2001). Rewarded by Punishment: Reflections on the Disuse of Positive Reinforcement in Schools. Exceptional Children, 67(2), 173-186.

Mayer, G. R. (1995). Preventing antisocial behavior in the schools. Journal of Applied Behavior Analysis, 28, 467-478. http://dx.doi.org/10.1901/jaba.1995.28-467

Mc Intire, R.W. (1996). Teenagers and parents. Columbia: Suumit crossroads press, Minet, P. (2005). Child care and development ( $5^{\text {th }}$ edition) John Murray publishers, London Ministry of Education. (1995). Tanzania Education and Training policy. Retrieved May 25, 2013, from http://www.tzonline.org/pdf/Educationandtrainingpolicy01.pdf

Mishra, R. C. (2007). Classroom management. New Delhi: APH Publishing Corporation Myers, D. G. (2001). Psychology., U.S.A: Worth publishers.

Myers, D. G. (2003). Exploring Psychology (5 ${ }^{\text {th }}$ edition) in Modules, U.S.A: Worth Publishers.

Nakpodia, E. D. (2010). Teacher's disciplinary approaches to students 'discipline problems in Nigerian secondary schools. Educational Research and review, 5(6), 144-151

Nerborig, M. H., \& Klausmeir, H. J. (1956). Teaching in the Elementary school, $4^{\text {th }}$ edition, New York: Harper \& Brothers.

Ofoyuru, T. D., \& Lawrence, T. (2011). Strategies of managing students discipline in secondary schools in Gulu district. Educational research and review, 3(11), 233- 236 
Orit, D. (2007). Developing democracy or promoting disruption? Educators' perceptions of the department of Education's current policy in classroom management. Unpublished thesis.

Parker, I. (1999). Critical textwork: Introduction to varieties of discourse and analysis. Buckingham: Open University Press.

Petty, G. (2004). Teaching today. United Kingdom: Nelson Thornes Ltd.

Prosser, J. (1999). The evolution of school culture research in J. Prosser (Ed.) School culture, London: PCP Ltd.

Rhodes, W. C., \& Michael, L. T. (1974). A study of Childs Variance. U.S.A: University of Michigan.

Savage, T.V., \& Savage, K.M. (2010). Successful Classroom Management and discipline ( ${ }^{\text {rd }}$ Edition) Sage Publishers: United Kingdom.

Simatwa, E.M.W. (2012). Management of student discipline in secondary schools in Kenya: A case study of Bungoma County, International Research Journals, 3(1), 172-189.

Skiba, R., \& Peterson, R. (2000). School discipline at a crossroads: From zero tolerance to early response. Exceptional Children, 32, 200-216.

Smit, M. E. (2010). The role of discipline in combating violence in schools in the East London region. East London: University of Fort Hare

Square, G. (2007). Children's care, learning and development, Heinemann, United Kingdom

Stolp, S. (1994). Leadership for school culture. Education Management, 91, 1-5.

Straus, M. A., Gelles, R. J., \& Steinmetz, S. K. (1980). Behind closed doors: Violence in the American family New York: Doubleday/Anchor Books.

Sugai, G. (1998). Postmodernism and emotional and behavioral disorders: Distraction or advancement. Behavioral Disorders, 23, 171-177.

Sugai, G., \& Horner, R. H. (1999). Discipline and behavioral support: Practices, pitfalls, \& promises. Effective School Practices, 17(4), 10-22.

Tshabangu, I. (2008). Education and violence: The Schools' micro-politics and the macro-politics in Zimbabwe. Educational Research and review, 3 (6), 219-228

UNICEF. (1999). Children's Rights and responsibilities. Retrieved May 28, 2013, from: www.unicef.org/rights site/files/rights_ leaflet

UNICEF. (2010). Ending corporal punishment and other cruel and degrading punishment of children through law reform and social change, Retrieved June 22, 2013, from: http://www.acabarcastigo.org/wp-content/uploads/2011/10/Ending-corporal-punishment-andother-cruel-and-degrading-punishment-of-children.pdf

UNICEF. (2011). Violence against children in Tanzania; Findings from a National survey, 2009, Retrieved May 22, 2013, from 


\section{Macrothink}

Journal of Studies in Education

ISSN 2162-6952 2013, Vol. 3, No. 4

http://www.unicef.org/media/files/VIOLENCE_AGAINST_CHILDREN_IN_TANZANIA_R EPORT.pdf

Williams, M. G.(2009). Violence in Education, the schools politics of discipline. Proquest LLC, U.S.A

Wolff, S. (1971). Children under Stress. London: Penguin Press.

Yahaya, A. Ramli, J. Hashim, S., Ibrahim, M.A., Raja, R. R., Rahman, A., \& Yahaya, N. (2009). Discipline problems among secondary school students in Johor Bahru. Educational Research and review, 11(4), 659- 675.

Yang, K. W. (2009). Discipline or punish? Some suggestions for school policy and teacher practice. Educational research and review, 87(1), 49-61. 